\title{
Trump, US climate politics, and the evolving pattern of global climate governance
}

DOI:

10.1080/14781158.2020.1675620

\section{Document Version}

Accepted author manuscript

Link to publication record in Manchester Research Explorer

\section{Citation for published version (APA):}

MacNeil, R., \& Paterson, M. (2019). Trump, US climate politics, and the evolving pattern of global climate governance. Global Change, Peace and Security, 1-18. https://doi.org/10.1080/14781158.2020.1675620

\section{Published in:}

Global Change, Peace and Security

\section{Citing this paper}

Please note that where the full-text provided on Manchester Research Explorer is the Author Accepted Manuscript or Proof version this may differ from the final Published version. If citing, it is advised that you check and use the publisher's definitive version.

\section{General rights}

Copyright and moral rights for the publications made accessible in the Research Explorer are retained by the authors and/or other copyright owners and it is a condition of accessing publications that users recognise and abide by the legal requirements associated with these rights.

\section{Takedown policy}

If you believe that this document breaches copyright please refer to the University of Manchester's Takedown Procedures [http://man.ac.uk/04Y6Bo] or contact uml.scholarlycommunications@manchester.ac.uk providing relevant details, so we can investigate your claim.

\section{OPEN ACCESS}




\title{
Trump, US climate politics, and the evolving pattern of global climate governance
}

\author{
Robert MacNeil, University of Sydney \\ Matthew Paterson, University of Manchester
}

\begin{abstract}
This paper argues that the Trump administration's position on climate change should be understood more in terms of continuity than disjuncture. It develops this argument in four principal ways. First, it situates Trump in the US's paradoxical relationship to the UNFCCC, as a would-be leader that struggles to commit itself to substantive action, and the evolving geopolitics within the UNFCCC. Second, the paper focuses on an on-going struggle between pro-fossil fuel interests and a 'decarbonising' bloc, interpreting Trump (like George W. Bush) as a pro-fossil fuel backlash. Third, it explores the pattern of climate politics within the US, where stalemate in Congress has been often offset by action at the state, city, and corporate levels. Fourth, it should be understood in relation to the emergence of a 'global climate governance complex', where the UNFCCC has to be understood in relation to multilevel and transnational governance initiatives on climate change.
\end{abstract}

\section{Keywords}

Climate change; Trump; US politics; UNFCCC; political economy

\section{Introduction}

Though climate change played only a minor role in Donald Trump's 2016 United States presidential campaign rhetoric, climate policy was key to numerous economic constituencies backing Trump - many of whom viewed him as, in effect, an empty vessel without many ideas of his own. They thus saw in him an opportunity not only to roll back various bits of climate and energy policy that the previous Obama administration had introduced, but to go much further and open up various novel areas for fossil fuel exploration and exploitation, as well as roll back many other environmental regulations going back to the Clean Air and Clean Water Acts of the early 1970s. In the wake of his inauguration, Trump's cabinet officials and Republican Congressional leaders wasted little time in making climate and energy one of the government's most active policy files (see Table 1), with major initiatives to roll back the Clean Power Plan, withdraw from the Paris Agreement (PA), and open up new federal lands to fossil fuel operations.

Table 1

Trump's Climate and Energy Rollbacks Rollbacks Completed as of 2019 Rollbacks in Process as of 2019 


\begin{tabular}{|c|c|}
\hline $\begin{array}{l}\text { Cancelled requirement for oil/gas companies } \\
\text { to report methane emissions. }\end{array}$ & $\begin{array}{l}\text { Proposed weakening national fuel-economy } \\
\text { standards. Also challenges California's right to set its } \\
\text { own more stringent standards. }\end{array}$ \\
\hline $\begin{array}{l}\text { Partially repealed rule limiting methane emissions on } \\
\text { public lands, including venting/flaring from drilling. }\end{array}$ & $\begin{array}{l}\text { Announced intent to withdraw US from the Paris } \\
\text { climate agreement. }\end{array}$ \\
\hline $\begin{array}{l}\text { Loosened rule limiting toxic emissions from major } \\
\text { industrial polluters. }\end{array}$ & $\begin{array}{l}\text { Proposed repeal of Clean Power Plan, which would } \\
\text { set limits on carbon emissions from coal- and gas- } \\
\text { fired power plants. }\end{array}$ \\
\hline $\begin{array}{l}\text { Stopped enforcing rule prohibiting use of } \\
\text { hydrofluorocarbons in air-conditioners and } \\
\text { refrigerators. }\end{array}$ & $\begin{array}{l}\text { Proposed eliminating restrictions that required newly } \\
\text { built coal power plants to capture carbon emissions. }\end{array}$ \\
\hline $\begin{array}{l}\text { Repealed requirement for states to track tailpipe } \\
\text { emissions from vehicles on federal highways. }\end{array}$ & $\begin{array}{l}\text { Proposed weakening a rule that limited mercury } \\
\text { emissions from coal power plants. }\end{array}$ \\
\hline $\begin{array}{l}\text { Reverted to a weaker } 2009 \text { pollution permitting } \\
\text { program for new power plants. }\end{array}$ & $\begin{array}{l}\text { Proposed revisions to standards for carbon emissions } \\
\text { from new and modified power plants. }\end{array}$ \\
\hline $\begin{array}{l}\text { Weakened rules governing how refineries monitor } \\
\text { pollution in surrounding communities. }\end{array}$ & $\begin{array}{l}\text { Proposed overturning rule that companies } \\
\text { monitor/repair methane leaks at oil/gas facilities. }\end{array}$ \\
\hline $\begin{array}{l}\text { Repealed Obama-era calculation of the 'social cost } \\
\text { of carbon' that rulemakers used to estimate economic } \\
\text { benefits of reducing carbon emissions. }\end{array}$ & $\begin{array}{l}\text { Proposed overturning rules aimed at cutting methane } \\
\text { emissions from landfills. }\end{array}$ \\
\hline $\begin{array}{l}\text { Withdrew rule that federal agencies include GHG } \\
\text { emissions in environmental reviews. }\end{array}$ & $\begin{array}{l}\text { Proposed overturning leak-repair and reporting } \\
\text { requirements for large refrigeration/air conditioning } \\
\text { systems containing hydrofluorocarbons. }\end{array}$ \\
\hline $\begin{array}{l}\text { Overturned water pollution regulations for fracking } \\
\text { on federal land. }\end{array}$ & $\begin{array}{l}\text { Completed preliminary environmental reviews to } \\
\text { allow drilling in the Arctic National Wildlife Refuge. }\end{array}$ \\
\hline $\begin{array}{l}\text { Overturned a rule that required mines to prove they } \\
\text { could afford the costs of cleaning up their pollution. }\end{array}$ & $\begin{array}{l}\text { Proposed opening most of America's coastal waters } \\
\text { to offshore oil and gas drilling. }\end{array}$ \\
\hline $\begin{array}{l}\text { Withdrew a rule that oil rig owners prove they could } \\
\text { afford the costs of removing rigs once they have } \\
\text { stopped producing. }\end{array}$ & $\begin{array}{l}\text { Proposed lifting an Obama-era freeze on new coal } \\
\text { leases on public lands. }\end{array}$ \\
\hline Approved construction of Dakota Access pipeline. & $\begin{array}{l}\text { Repealed a rule governing royalties for oil/gas/coal } \\
\text { leases on federal lands which forced companies to } \\
\text { pay a greater share to the federal government. }\end{array}$ \\
\hline $\begin{array}{l}\text { Announced intent to stop payments to the UN's } \\
\text { Green Climate Fund }\end{array}$ & $\begin{array}{l}\text { Proposed streamlining approval process for oil/gas } \\
\text { drilling in national forests. }\end{array}$ \\
\hline $\begin{array}{l}\text { Revoked rules governing how the Federal Energy } \\
\text { Regulatory Commission considers the indirect } \\
\text { effects of GHG emissions in environmental reviews } \\
\text { of pipelines. }\end{array}$ & $\begin{array}{l}\text { Proposed overturning regulations on offshore oil /gas } \\
\text { exploration in the Arctic }\end{array}$ \\
\hline $\begin{array}{l}\text { Loosened offshore drilling safety regulations } \\
\text { implemented after the } 2010 \text { Gulf oil spill. }\end{array}$ & $\begin{array}{l}\text { Approved the Keystone XL pipeline (the project } \\
\text { remains tied up in court). }\end{array}$ \\
\hline $\begin{array}{l}\text { Rolled back the environmental review process for } \\
\text { federal infrastructure projects. }\end{array}$ & $\begin{array}{l}\text { Proposed stripping Endangered Species Act of key } \\
\text { provisions. }\end{array}$ \\
\hline $\begin{array}{l}\text { Revoked executive order which withdrew local } \\
\text { waters from oil and gas leasing. }\end{array}$ & $\begin{array}{l}\text { Proposed overturning regulation that doubled the } \\
\text { number of light bulbs subject to energy-efficiency } \\
\text { standards. }\end{array}$ \\
\hline $\begin{array}{l}\text { Revoked executive order that set a goal of cutting the } \\
\text { federal government's GHG emissions by } 40 \% \text { over } \\
10 \text { years. }\end{array}$ & $\begin{array}{l}\text { Proposed overturning efficiency standards for } \\
\text { residential furnaces and water heaters. }\end{array}$ \\
\hline $\begin{array}{l}\text { Eliminated a planning system designed to } \\
\text { minimize harm from oil/gas drilling on sensitive } \\
\text { landscapes. }\end{array}$ & $\begin{array}{l}\text { Proposed removing climate change considerations } \\
\text { from the government's National Security Strategy. }\end{array}$ \\
\hline $\begin{array}{l}\text { Opened nine million acres of land to oil/gas drilling } \\
\text { by weakening habitat protections. }\end{array}$ & $\begin{array}{l}\text { Through its budget proposals, the administration has } \\
\text { sought to slash the DOE's renewable energy R\&D } \\
\text { budget by nearly } 70 \% \text {, and reduce the EPA's overall } \\
\text { operating budget by nearly } 25 \% \text {. }\end{array}$ \\
\hline
\end{tabular}


Source: Nadja Popovich, Livia Albeck-Ripka, and Kendra Pierre-Louis. 83 Environmental Rules Being Rolled Back Under Trump, New York Times, June 7, 2019, https://www.nytimes.com/interactive/2019/climate/trumpenvironment-rollbacks.html

The general reaction from many commentators and academics has (understandably, given the evidence laid out in Table 1) been to regard Trump's actions as both destructive in their implications, and highly discontinuous with the strategies of previous administrations, especially Obama's. Such analyses have argued that Trump's positions on climate (both international and domestic) are likely to undermine international emissions reduction efforts ${ }^{1}$, reduce participation in the Paris Accord ${ }^{2}$, encourage the rise of anti-climate forces around the globe $^{3}$, reduce funding for adaptation in developing countries ${ }^{4}$, hinder the US' (and the world's) transition away from fossil fuels ${ }^{5}$, and leave the global climate regime without any significant leadership ${ }^{6}$ - among many other concerns.

While Trump's interventions have undeniably been harmful (as these commentators rightly note), we argue in this paper that the story of US climate policy under Trump is actually better understood as one of general continuity with the country's overall approach since the late 1980s. Put succinctly, while Trump represents an unhelpful addition to the story, US climate policy has always been extremely dysfunctional, complex, and grossly inadequate. Our key goal in this paper is thus to provide an offset to the emerging conventional wisdom around Trump's climate policies, and argue that overstating his impact (as well as overemphasizing the achievements of the Obama administration) obscures the broader trends and trajectory of Washington's actions, and how it interacts with broader global forces.

We develop this argument by situating Trump's climate strategy in four different key dynamics within climate change politics. First, we situate it internationally, within the long development of the US' paradoxical relationship with the UNFCCC - a treaty on which Washington has see-sawed back-and-forth from would-be leader to disgruntled spoiler for more than a quarter of a century. Second, we situate it in terms of US political economy, in relation to a decades-long shift within the US' domestic energy market which Trump is merely continuing and hastening. Third, we situate it in relation to US domestic political dynamics, specifically, within a complex pattern of domestic US climate governance underway since the mid-1990s, where inaction at the federal level produces significant action

\footnotetext{
${ }^{1}$ Frank Jotzo, Joanna Depledge, and Harald Winkler, 'US and international climate policy under President Trump', Climate Policy 18, no. 7 (2018): 813-817; Jonathan Pickering, Jeffrey S. McGee, Tim Stephens \& Sylvia I. Karlsson- Vinkhuyzen, 'The impact of the US retreat from the Paris Agreement: Kyoto revisited?', Climate Policy, 18, no. 7 (2018): 818-827; Rebecca Leber, 'Even if Trump doesn't "cancel” the Paris deal, he could still ruin it’. Grist.org, June 2017, https://grist.org/article/even-if-trump-doesnt-cancel-the-paris-deal-hecould-still-ruin-it/

${ }^{2}$ Detlef F. Sprinz, Håkon Sælen, Arild Underdal \& Jon Hovi, 'The effectiveness of climate clubs under Donald Trump, Climate Policy 18, no. 7 (2018): 828-838; Joe Romm, 'Domino effect: Turkey won't ratify Paris climate accord, citing Trump's exit', Think Progress, June 2017, https://thinkprogress.org/turkey-follows-trump-parisclimate-accord-39fb0d573164/

${ }^{3}$ Johannes Urpelainen \& Thijs Van de Graaf, 'United States non-cooperation and the Paris agreement', Climate Policy 18, no. 7 (2018): 839-851.

${ }^{4}$ Luke Kemp, 'Better out than in', Nature Climate Change, 7 (2017): 458-460; Urpelainen and Van de Graaf, 'United States non-cooperation'.

${ }^{5}$ Jan Selby, 'The Trump presidency, climate change, and the prospect of a disorderly energy transition', Review of International Studies 45, no. 3 (2018): 471-490; Brad Plumer, 'Trump will officially start hacking away at Obama's climate policies on Tuesday', Vox.org, June 2017, https://www.vox.com/energy-andenvironment/2017/3/27/15073522/trump-order-obama-climate-policies

${ }^{6}$ Natasha Geiling, 'What happens now that Trump pulled the US out of the Paris agreement?' Grist.org, June 2017, https://thinkprogress.org/wont-always-have-paris-agreement-sad-1d718470b3de/
} 
within the states and courts. And finally, we situate it transnationally, in relation to the ongoing development of a 'global climate governance complex', where the PA within the UNFCCC has to be situated in multilevel and transnational governance initiatives on climate change.

\section{Continuity \#1: Trump, the US and the UNFCCC}

The relationship between the US and the UNFCCC has been at best hesitant. Indeed in part this is reflective of a long ambivalence about multilateralism going back to the failure of the US to ratify the United Nations Conference on the Law of the Sea after 1982, to enable the establishment of the International Trade Organization in 1950, or to join the League of Nations after 1919, despite playing a leading role in the negotiations that created all three of these. But in climate change, if anything the oscillations in this ambivalence have become sharper over time. Domestically, climate change has become a partisan issue since the mid2000s and partisanship has become considerably more hostile. As a result, while Bush Jr.'s relationship to the UNFCCC differed from that of Clinton a little, that between Obama and Trump is much greater. The US position has had two major periods of rejection of the FCCC process, with Bush Jr. rejecting the Kyoto Protocol in 2001 and Trump stating in 2017 that he will withdraw the US from the PA. Trump's rhetoric has been considerably more hostile than was that of Bush, and his domestic attempts at rollback more serious, but it doesn't fall outside the overall pattern.

Even when the US has had administrations constructively engaged with the UNFCCC process, under Bush senior, Clinton and Obama, it has done so in a way that reflects its own sense of geopolitical identity, the demands of a hegemonic power in imposing its will on multilateral negotiations. ${ }^{7}$ Under Bush senior, the US was the only industrialised country opposed to including binding emissions targets in the UNFCCC in 1992, preferring a looser 'aim' to control emissions. ${ }^{8}$ Under Clinton it played the leading role in the design of the Kyoto Protocol in 1997, notably in insisting on the inclusion (over the objections of most other countries) of market-based mechanisms: emissions trading, joint implementation, and the Clean Development Mechanism. ${ }^{9}$ And under Obama, the US led the charge for a socalled 'bottom up' design for an agreement to replace the 'top-down' Kyoto, against the wishes of the great majority of other countries that would have preferred a 'legally binding' agreement over the 'pledge and review' design of what became the PA. The impasse produced by this dynamic between the US-led strategy centred on key partners (China, India, the EU) and the resistance of other countries (Bolivia, Venezuela, notably) was one of the principal reasons for the failure to agree a new treaty at Copenhagen in 2009, although other factors such as the tactics of the Danish presidency were also important. ${ }^{10}$

\footnotetext{
${ }^{7}$ Matthew Paterson, 'Post-hegemonic climate politics?', British Journal of Politics and International Relations 11 (2009): 140-158; see also Charles F. Parker and Christer Karlsson, 'The UN climate change negotiations and the role of the United States: assessing American leadership from Copenhagen to Paris', Environmental Politics 27, no. 3 (2018): 519-540.

${ }^{8}$ Matthew Paterson, Global Warming and Global Politics (London: Routledge, 1996).

${ }^{9}$ Michael Grubb, Duncan Brack, and Christiaan Vrolijk, The Kyoto Protocol: A Guide and Assessment, (London: Earthscan, 1999); Alexander Ovodenko and Robert O. Keohane, 'Institutional diffusion in international environmental affairs', International Affairs 88, no. 3 (2012): 523-541; but cf. Matthew Paterson, Matthew Hoffmann, Michele Betsill, and Steven Bernstein, 'The Micro Foundations of Policy Diffusion Toward Complex Global Governance An Analysis of the Transnational Carbon Emission Trading Network', Comparative Political Studies 47, no. 3 (2014): 420-449.

${ }^{10}$ For various interpretations of the Copenhagen COP see Joanna Depledge, 'Crafting the Copenhagen Consensus: Some Reflections', Review of European Community \& International Environmental Law 17, no. 2
} 
Overall, therefore, there has been very significant continuity in the US's relationship to the UNFCCC, oscillating between a hegemonic multilateralism, imposing US preferences on the world, and a retreat to isolationist rejectionism. For much of the literature on the US engagement with the UNFCCC, the focus is on the question of US 'leadership' within the negotiations. ${ }^{11}$ Our analysis departs from this by making US leadership and isolation the flipside of each other: each competing expressions of US attempts at political dominance. Such analysis also fails to address the underlying continuities at the domestic level, where the structure of policy and ambition is similar across administrations, as we show below: US 'leadership' in the UNFCCC is rather divorced from the actual level of achievement within the US and thus needs to be understood in terms of the geopolitical ambitions of US elites rather than a serious commitment to multilateralism or climate leadership.

But alongside that however has been an increasing inability of the US to control the overall agenda, with other states or groups of states able to fill the void when the US does retreat into isolationism on climate change, thus meaning that the UNFCCC process itself is not in practice harmed by the US retreat. Indeed it may be helped as the reluctant teenager has left the room.

When Bush pulled the US out of the Kyoto Protocol, the Bush administration's expectation was clearly that Kyoto was, in Condoleeza Rice's words, 'dead'. ${ }^{12}$ However, what happened rather quickly was that the EU, rather than seeing the challenge of getting Kyoto to enter into force and then to work as insurmountable, decided to use it as an opportunity to exercise global leadership. ${ }^{13}$ They mounted a huge diplomatic effort to get the key states to ratify so that, with Kyoto's entry into force rules, it could do so. They then created a European emissions policy that generated huge demand for credits to be generated by Kyoto's flexibility mechanisms, especially the CDM. This was crucial in drawing large developing countries, especially China and India, into a position where they started to see their interests as consistent with those of the climate regime. The EU was so successful in this that by the mid-2000s, many American commentators and politicians were calling Kyoto a 'Eurocentric' regime, despite all its main rules and institutions being there at American insistence. So while Kyoto was clearly weakened by US non-participation, the system was institutionally rather robust and could survive abandonment by the world's superpower.

The Trump administration may have thought the same about Paris, and certainly a number of commentators have worried about whether it would weaken resolve among leading countries,

(2008): 154-165; Daniel Bodansky, 'The Copenhagen Climate Change Conference: A post-mortem', The American Journal of International Law 104, no. 2 (2010): 230-240; Lavanya Rajamani, 'The making and unmaking of the Copenhagen Accord', International and Comparative Law Quarterly 59, no. 3 (2010): 824843; Peter Christoff, 'Cold climate in Copenhagen: China and the United States at COP15', Environmental Politics 19, no. 4 (2010): 637-656.

${ }^{11}$ Charles F. Parker and Christer Karlsson, 'The UN climate change negotiations and the role of the United States: assessing American leadership from Copenhagen to Paris', Environmental Politics 27, no. 3 (2018): 519-540.

${ }^{12}$ As quoted in Alexander Ochs and Detlef Sprinz, 'Europa Riding the Hegemon? Transatlantic Climate Policy Relations', in Hegemony Constraint: Evasion, Modification, and Resistance to American Foreign Policy, ed. Davis B Bobrow and William Keller (Pittsburgh: University of Pittsburgh Press, 2008), 151.

${ }^{13}$ Jon Hovi, Tora Skodvin, and Steinar Andresen, 'The Persistence of the Kyoto Protocol: Why Other Annex I Countries Move on Without the United States', Global Environmental Politics 3, no. 4 (2003): 1-23; Miranda A Schreurs and Yves Tiberghien, 'Multi-Level Reinforcement: Explaining European Union Leadership in Climate Change Mitigation', Global Environmental Politics 7, no. 4 (2007): 19-46; Sebastian Oberthür and Claire Roche Kelly, 'EU Leadership in International Climate Policy: Achievements and Challenges', The International Spectator 43, no. 3 (2008): 35-50. 
causing them to slow down progress on their own decarbonization strategies, ${ }^{14}$ or emboldening other populist leaders in countries like Germany or most recently Brazil. ${ }^{15}$ The most plausible material threat is to the Green Climate Fund, where committed US money provided significant sources of the fund's resources. ${ }^{16}$ However, in the past committed funds have vastly outstripped actual finance provided, so how much practical impact this withdrawal would have is unclear. ${ }^{17}$

However, there are powerful reasons for thinking the impact on Paris will be much less than our worst fears (or of course, the hopes of Trump administration hawks). ${ }^{18}$ Shortly after Trump made his announcement, David Victor wrote provocatively that all he had done was cede leadership on the issue to China. ${ }^{19}$ The EU's capacity to lead on climate change had been weakened by Obama's attempt to renew American leadership from Copenhagen onwards, but also because of internal problems limiting its own capacity for leadership. The design of the PA also means that there is currently no mechanism like the CDM through which the EU could draw big developing countries into their orbit. But China's power had of course grown during this 15-year period significantly, both in general, and specifically in relation to climate change. We concentrate on the latter here, assuming the general picture is well known. ${ }^{20}$

As alluded to above, the CDM started to shift China's orientation to climate change. As Jinnah puts it, in part what was going on was a shift in China's relationship to the UNFCCC

\footnotetext{
${ }^{14}$ Jonathan Pickering, Jeffrey S. McGee, Tim Stephens, and Sylvia I. Karlsson-Vinkhuyzen, 'The impact of the US retreat from the Paris Agreement: Kyoto revisited?' Climate Policy 18, no. 7 (2018): 818-827; Jotzo, Depledge, and Winkler, 'US and international climate policy'.

15 Johannes Urpelainen and Thijs Van de Graaf, 'United States non-cooperation and the Paris agreement', Climate Policy 18, no. 7 (2018): 839-851.

${ }^{16}$ Luke Kemp, 'Better out than in', Nature Climate Change, 7 (2017): 458-460; Urpelainen and Van de Graaf, 'United States non-cooperation'.

17 Jan Selby, 'The Trump presidency, climate change, and the prospect of a disorderly energy transition', Review of International Studies 45, no. 3 (2018): 471-490.

${ }^{18}$ See also Michele M. Betsill, 'Trump's Paris withdrawal and the reconfiguration of global climate change governance', Chinese Journal of Population Resources and Environment 15, no. 3 (2017): 189-191.

${ }^{19}$ David Victor, 'What a Trump Win Means For the Global Climate Fight', Yale E360, November 2016, https://e360.yale.edu/features/what_donald_trump_win_means_for_global_climate_fight. See also Wanyun Shao, 'Trump's decision to withdraw from the Paris accord cedes global leadership to China', The Conversation, June 2, 2017; Henrik Selin, 'Trump's exit of Paris climate accord strengthens China and Europe', The Conversation, June 5, 2017; Zeeshan Aleem, 'Trump pulling out of the Paris climate agreement is great news ... for China', Vox, June 3, 2017; Luke Kemp, 'Better out than in', Nature Climate Change 7 (2017): 458460.

${ }^{20}$ A case can be made that this shift is broader than just the rise of China, but more of a BRICS or BASIC phenomenon. There has been a significant literature on this since the late 2000s. But we would make the case for the distinctiveness of China in this context. At both Copenhagen and Paris, US-China bilateral coordination was central to the process leading up to the conferences, and arguably central to the success at Paris (alongside various other factors). Only China has global emissions levels combined with the sort of geopolitical clout which means the US takes it seriously as a rival, which is what makes it central to how US strategy on climate has played out. See variously. Navroz K. Dubash, Radhika Khosla, Ulka Kelkar, and Sharachchandra Lele, 'India and Climate Change: Evolving Ideas and Increasing Policy Engagement', Annual Review of Environment and Resources 43, no. 1 (2018): 395-424; Andrew Hurrell and Sandeep Sengupta, 'Emerging powers, NorthSouth relations and global climate politics', International Affairs 88 no. 3 (2012): 463-484; Karl Hallding, Marie Jürisoo, Marcus Carson, and Aaron Atteridge, 'Rising powers: the evolving role of BASIC countries', Climate Policy 13, no. 5 (2013): 608-631; Hayley Stevenson, 'India and international norms of climate governance: a constructivist analysis of normative congruence building', Review of International Studies 37, no. 3 (2011): 997-1019.
} 
from norm-taker to norm-maker. ${ }^{21}$ But this shift also has an important political economy underpinning in the opportunities created first by the CDM, and then more generally in the opportunities in renewable energy. For most of the period since climate negotiations began (and we still have echoes of this in their rhetoric), the Chinese position, like that of most developing countries, was that climate change was caused by emissions from industrialized countries, and developing countries thus had no responsibility for reducing emissions. Any actions to reduce emissions by developing countries would have to be financed by

industrialized countries. But the CDM create a flow of funds and technology to China, mostly via private investments, that created opportunities for Chinese firms and the Chinese state. ${ }^{22}$ China has dominated the CDM among host countries, with around 56\% of all CDM projects being located in China. ${ }^{23}$ They started to engage in reverse-engineering some of the technologies they were getting, for example regarding high-efficiency coal combustion, electric vehicles, and solar $\mathrm{pV} .{ }^{24}$ In other words, the CDM contributed to, alongside the broader transformations in China's political economy and the powerful domestic health and air pollution reasons to address China's coal use, a shift in orientation where China started to see its strategy as consistent with a shift to becoming a leader in both the manufacturing and installation of renewable energy. ${ }^{25}$

The result was that rapidly, China became the world's largest solar $\mathrm{pV}$ manufacturer and exporter, with a $60.4 \%$ share of global production in 2013 . It also produced $17.9 \%$ of world wind turbines in 2012, second only to Germany. ${ }^{26}$ But at the same time, China had a host of other domestic reasons, mostly to do with acute air pollution and thus health problem, to address its sources of GHGs. In response to this, coal use in China appeared to be plateauing and even modestly declining in the mid 2010s, ${ }^{27}$ although this has reversed since 2016 and Chinese coal use is again increasing. ${ }^{28}$ But installation of renewable energy was nevertheless prodigious: by 2015, China led the world in wind energy installation by a long way, with $30.7 \%$ of all globally installed capacity, and was second only to Germany in solar pV, with $15.6 \%$ of globally installed capacity. ${ }^{29}$ When put together with other aspects of Chinese geopolitical ambition, perhaps most importantly the 'One Belt, One Road' project, ${ }^{30}$ and its massive investment in various African countries, it is perhaps not surprising that China would seek to fill the void in leadership in the UNFCCC created by the Trump repudiation. Enacting leadership in climate change negotiations is connected to broader geopolitical ambitions and

\footnotetext{
${ }^{21}$ Sikina Jinnah, 'Makers, Takers, Shakers, Shapers: Emerging Economies and Normative Engagement in Climate Governance', Global Governance: A Review of Multilateralism and International Organizations 23, no. 2 (2017): 285-306.

22 Joanna I. Lewis, 'The evolving role of carbon finance in promoting renewable energy development in China', Energy Policy 38, no. 6 (2010): 2875-2886.

${ }^{23}$ See the CDM pipeline at: http://www.cdmpipeline.org/cdm-projects- region.htm.

${ }^{24}$ Jim Watson, Rob Byrne, David Ockwell, and Michele Stua, 'Lessons from China: building technological capabilities for low carbon technology transfer and development', Climatic Change 131, no. 3 (2015): 387-399.

${ }^{25}$ See notably John Mathews, Greening of Capitalism: How Asia Is Driving the Next Great Transformation, (Stanford CA: Stanford University Press, 2014); Watson et al, 'Lessons from China'.

${ }^{26}$ Erick Lachapelle, Robert MacNeil, and Matthew Paterson, 'The political economy of decarbonisation: from green energy "race" to green "division of labour", New Political Economy 22, no. 3 (2017): 317; Jonas Meckling and Llewelyn Hughes, 'Globalizing Solar: Global Supply Chains and Trade Preferences', International Studies Quarterly 61, no. 2 (2017): 225-235.

${ }^{27}$ See Qiang Wang and Rongrong Li, 'Decline in China's coal consumption: An evidence of peak coal or a temporary blip?', Energy Policy 108 (2017): 696-701. Official Chinese figures are however notoriously unreliable.

${ }^{28}$ IEA, Coal 2018. Analysis and Forecasts to 2023 (Paris: International Energy Agency, 2018).

${ }^{29}$ Lachapelle, MacNeil, and Paterson, 'The political economy of decarbonisation': 314.

${ }^{30}$ Flynt Leverett and Wu Bingbing, 'The New Silk Road and China's Evolving Grand Strategy', The China Journal 77 (2017): 110-132.
} 
specific economic interests. ${ }^{31}$

In the year following Trump's election, China showed tentative steps of moving into this leadership role. China quickly and repeatedly joined other countries in saying that they would not renegotiate the PA (as Trump had hinted he would try to do) but would rather redouble efforts to implement it. At COP22 in Marrakech, immediately following Trump's election, China, the EU, and Canada formed the 'Ministerial on Climate Action' coalition. ${ }^{32}$ In March 2017, the Chinese Ambassador to the UN, Liu Jieyi, made China's ambition clear, stating at a high-level UN event that China would still be aiming to peak its carbon emissions between 2025 and 2030, and that its combined policies to reach its NDC goals would create 69 million jobs. He also announced a set of measures of 'south-south cooperation' to help other developing countries shift to a low-carbon economy and adapt to climate change, a move widely interpreted as response to Trump's withdrawal of funds from the Green Climate Fund. ${ }^{33}$ A key moment came in June 2017, when the EU and China announced a bilateral initiative to 'lead the energy transition' towards decarbonisation. ${ }^{34}$ At the end of December 2017, China announced the plan to extend its municipal and provincial pilot carbon trading systems to a fully-fledged national system, although this may be plagued by the problems of other such systems. ${ }^{35}$

It is not certain that such leadership will translate into the accelerated action on climate change that most commentators recognise is needed. And during 2018 the promise of the many initiatives that came shortly after Trump's election was at best ambiguously realised. Assessments of COP24 in Katowice were generally that progress had slowed during 2018 and the outcome was very disappointing. ${ }^{36}$ But at the same time China's commitment procedurally to keeping negotiations going under threat from US, Australian, Saudi and Polish recalcitrance was widely noted. ${ }^{37}$ And again, a story of recurrent setbacks in UNFCCC negotiations is a story of continuity, not of disruptive change.

\section{Continuity \#2: Coal and gas in the US political economy}

Trump's promise to revitalize the US coal industry by scrapping Obama's Clean Power Plan stood as one of the biggest concerns for pro-climate forces. Yet, interestingly, Trump's

\footnotetext{
${ }^{31}$ Chris G. Pope, 'China wants to dominate the world's green energy markets - here's why', The Conversation (January 12, 2018); Liang Dong, 'Bound to lead? Rethinking China's role after Paris in UNFCCC negotiations', Chinese Journal of Population Resources and Environment 15, no. 1 (2017): 32-38; Urpelainen and Van de Graaf, 'United States non-cooperation'.

32 Jocelyn Timperley, 'COP23: Key outcomes agreed at the UN climate talks in Bonn', Carbon Brief, (19 November 2017).

${ }^{33}$ Karl Mathiesen, 'This is China's strongest statement yet on climate action', Climate Home News, March 30, 2017.

${ }^{34}$ As quoted in Daniel Boffey and Arthur Neslen, 'China and EU strengthen promise to Paris deal with US poised to step away', The Guardian, June 1, 2017. See also Aleem, 'Trump pulling out'; David Stanway and Henning Gloystein, 'No longer "climate bad boy," China steps up as Trump quits Paris deal', Reuters, June 2, 2017.

${ }^{35}$ Keith Bradsher and Lisa Friedman, 'China Unveils an Ambitious Plan to Curb Climate Change Emissions', The New York Times, December 19, 2017.

36 Julia Conley, 'Morally Unacceptable': Final Deal Out of COP24 Sorely Lacking in Urgency and Action, Climate Campaigners Say. Common Dreams, December 15, 2018,

https://www.commondreams.org/news/2018/12/15/morally-unacceptable-final-deal-out-cop24-sorely-lackingurgency-and-action-climate.

${ }^{37}$ Lily Hartzell, 'A Shift in Climate Strategy: China at the COP24', China-US Focus, January 25, 2019, https://www.chinausfocus.com/energy-environment/a-shift-in-climate-strategy-china-at-the-cop-24.
} 
actions in office have really only helped the coal industry at the margins - mostly by making it easier to obtain federal permits for mining operations, and scrapping some of the more unfavourable policies that were dogging the industry. ${ }^{38}$ In truth, the Obama administration's coal regulations had little to do with the industry's decline over the past generation. Estimates by the US Energy Information Administration (EIA) suggest that the real culprit is not federal regulation, but rather the influx of cheap natural gas into the energy market, brought about by the rapid expansion of hydraulic fracturing (fracking). According to the EIA, as much as 80 percent of coal's decline is directly attributable to the 'fracking boom', which resulted in the closure of 268 coal plants between 2010 and 2017. ${ }^{39}$ The EIA's projections suggest that the decline of thermal coal for electricity will accelerate Obama's Clean Power Plan (CPP) and other regulations - particularly as new pipelines come online, and the gas industry delivers on its plans to build 25 gigawatts of new generating capacity by 2020 . Given this competition, coal retirements actually ramped-up following Trump's election, with more coal capacity closing in the first 45 days of Trump's tenure than in each of the first three years of the Obama administration - roughly one coal facility every 16 days. ${ }^{40}$

As a result, efforts to repeal Obama-era regulations have not made a significant difference. As part of its initial rationale, Obama's Clean Power Plan aimed to arrive at a national energy mix of 33 percent natural gas and 27 percent coal by 2030. Yet without the plan ever coming into effect, this ratio has effectively already been achieved by 2018 (for perspective, in 2003 coal provided 51 percent of US electricity, and natural gas just 17 percent), and the EIA projects that most of the country's remaining 262 coal plants will close over the next decade. ${ }^{41}$ Likely the only plausible hope for US coal now is exports. However, the key export markets (China and Europe) are themselves looking to transition away from coal, and China is striving to dramatically reduce fossil fuel imports. Given the high price of exporting coal from the US (in light of the costs of inland transport and overseas shipping), a thermal coal price of at least $\$ 70$ per tonne is required to make a profit. If more countries transition away from coal over the coming years, this price is likely to drift further to a level where US exports are unprofitable.

\section{FIGURE 1 IN ABOUT HERE}

Figure 1. Trends in fuel mix in US electricity generation

Ironically, Trump's policies will likely hasten coal's decline as his administration has opened more drilling rights on federally owned land, bringing the total public land available for drilling to nearly 600 million acres, or roughly a quarter of the US' entire land surface. Along with this, Trump issued directives that hollowed out the environmental review process for fracking, eliminated public input on drilling proposals, and ended the designation of 'master leasing plans' that sought to steer fracking away from communities, threatened species, and other sensitive lands. These efforts will further flood the US market with cheaper natural gas, making the country's remaining coal installations even less competitive. ${ }^{42}$

\footnotetext{
${ }^{38}$ In this context, Trump suggested that he has officially ended the 'war on coal', and pointed to a slight uptick in the number of US coal-mining jobs in his first year. This uptick, however, was not a result of federal policy changes, but rather an anomalous increase in metallurgical coal exports to Asia, which were the result of a cyclone that knocked out production in Northeastern Australia, thereby creating space for US exports.

${ }^{39}$ Energy Information Administration, Annual Energy Outlook 2018, https://www.eia.gov/outlooks/aeo/

${ }^{40}$ Idem. For more on this, particularly its international dimensions, see Tim Boersma and Corey Johnson, U.S.

Energy Diplomacy, (New York, Columbia Center on Global Energy Policy 2018).

${ }^{41}$ Energy Information Administration. Annual Energy Outlook 2018: figure 1.

42 Trump's only plausible pitch to save the coal industry was a 2017 proposal to use federal money to prop up US power plants capable of storing a 90-day fuel supply on site (something which coal and nuclear facilities can
} 
Given that natural gas emits less $\mathrm{CO}_{2}$ than coal, this transition has allowed the US' electricity sector emissions to achieve a marked decline since 2005. And, in light of Trump's continuation of pro-gas policies, Galik et al find that federal policy under Trump will have effectively zero impact on decarbonization trends in this sector. ${ }^{43}$

But the news here is not entirely positive. While declining emissions in the electricity sector will continue under Trump (and likely his successor), the current trajectory is not remotely sufficient. For the US to achieve deep decarbonization and do its share to avoid climate chaos, it is not enough for electricity emissions to moderately decline, they must rapidly head for zero by the early 2030s. This is a monumental undertaking, and the US is not even slightly on track to do it.

As Selby and others point out, natural gas is not a panacea, and its usage must rapidly decline and fall to zero - not continue to increase or even gently decline. ${ }^{44}$ Beyond the obvious $\mathrm{CO}_{2}$ emissions created by natural gas, there are four other reasons why this must be the case. First, fracking creates enormous methane emissions (a greenhouse gas that is 25 times more potent than $\mathrm{CO}_{2}$ ), making it antithetical to the goal of climate change mitigation, and perhaps completely overriding any $\mathrm{CO}_{2}$ emissions saved by burning gas instead of coal. ${ }^{45}$ Second, the fracking boom in the US has been a key factor keeping the global price of oil and gas persistently low over the past decade. This, in turn, has discouraged badly-needed global investments in renewable technologies. Third, the construction of expensive natural gas infrastructure is likely to 'lock-in' its continued use for decades to come, making future decarbonization efforts even more complicated. And finally, the rise of a powerful new element of the US fossil fuel industry is bound to have an impact on the US' global approach to climate change - particularly as it makes the US a net exporter of fossil energy. One could easily imagine a scenario where an increasingly powerful gas lobby helps to entrench Washington's support for fossil fuels even after the demise of coal.

In brief, these trends in the electricity sector predate Trump by almost forty years (the US government developed the process of hydraulic fracturing in the late 1970s, and has been promoting it ever since), and his interventions have only hastened the trajectory. Yet, his presence is nevertheless damaging. While Obama was arguably the strongest proponent of fracking ever to occupy the White House - opening millions of acres of federal land for exploration and approving new pipelines, terminals, and every LNG export license presented

do, but which renewables and natural gas cannot, at the moment). However, the Federal Energy Regulatory Commission - stacked with Trump's own appointees - unanimously rejected the proposal, leaving the coal industry with no remaining lifelines.

${ }^{43}$ Christopher S. Galik, Joseph F. DeCarolis, and Harrison Fell, 'Evaluating the US Mid-Century Strategy for Deep Decarbonization amidst early century uncertainty', Climate Policy 17, no. 8 (2017): 1046-1056.

${ }^{44}$ Selby, 'The Trump presidency'.

${ }^{45}$ Christophe McGlade and Paul Ekins, 'The geographical distribution of fossil fuels unused when limiting global warming to $2{ }^{\circ} \mathrm{C}$ ', Nature 517 (2015): 187-190; Christophe McGlade and Paul Ekins, 'Un-burnable oil: An examination of oil resource utilisation in a decarbonised energy system', Energy Policy 64 (2014): 102-112. Nevertheless, some remain confident that natural gas can play a key role in decarbonising the US energy grid, as long as carbon capture and storage technologies decline in price sufficiently over the coming decades. See Department of Energy, Carbon Capture Opportunities for Natural Gas Fired Power Systems, (US Department of Energy 2019), https://www.energy.gov/sites/prod/files/2017/01/f34/Carbon\%20Capture\%20Opportunities\%20for\%20Natural \%20Gas\%20Fired\%20Power\%20Systems_0.pdf; R. S. Elias, M. I. M. Wahab, and L. Fang, 'Retrofitting carbon capture and storage to natural gas-fired power plants: A real-options approach', Journal of Cleaner Production 192 (2018): 722-734. 
to him $^{46}$ - he was also avowedly pro-renewables, and sought to shore-up billions of dollars to support R\&D, manufacturing, and installation of these technologies. The Clean Power Plan also created a symbolic guide for the utility industry, sending a meaningful signal that decarbonizing technologies were the only path forward. Trump has, at least somewhat, disrupted this. Utility Dive's 'State of the Electric Utility' survey in 2018 of more than 600 US utility executives showed that an overwhelming majority were unnerved by the regulatory uncertainty that Trump had introduced into the market, particularly his efforts to roll-back carbon regulations and alter wholesale power markets to benefit non-renewable sources. ${ }^{47}$

\section{Continuity \# 3: 'Alternative climate policy pathways' in the US polity}

US presidents have historically had limited power over climate policy. This was the case for Clinton, Bush Jr., and Obama, all of whom saw their climate policies - both progressive and regressive ones - struggle against a series of institutional ramparts. On this score, Trump has been unexceptional, with his major reforms running headlong into a complex political system replete with veto points capable of blocking most of his retrograde policies, and full of socalled 'alternative policy pathways' capable of facilitating continued forward action for proclimate forces. ${ }^{48}$

The first veto point thus far has been Congress. Like all of his predecessors over the past quarter century, Trump has failed to pass any major environmental policy through the legislative process, despite the Republican Party controlling both the upper and lower houses. With Senate Democrats able to filibuster any major rollbacks (and House Republicans keen to maintain the federal largesse of agencies like EPA, DOE, NASA, NOAA, and ARPA-E located in their districts), no particularly retrograde environmental or climate policies have achieved legislative passage.

Trump has also been hemmed in by the court system. The biggest single example of this has been his efforts to scrap Obama's Clean Power Plan. Under the constitution, a president cannot simply file an executive order to kill this type of regulation. Rather, they can merely request a 'revision or replacement', which takes many years, and requires the administration to not only produce a compelling scientific reason for why regulating $\mathrm{CO}_{2}$ is unnecessary (not at all certain to be accepted), but it then must endure a lengthy 'notice and comment' period during which millions of comments will be made, and then must be answered. ${ }^{49}$ This is followed by a long period of judicial review, where litigation from numerous environmental, health, and community groups is filed and prosecuted. Even if these groups are unsuccessful, the whole process will take years to complete. Beyond the Clean Power Plan, many of Trump's climate goals have been swamped by litigation from the 50 states, which have challenged the administration (often successfully) in court on effectively every major climate rollback.

\footnotetext{
${ }^{46}$ Selby, 'The Trump presidency'.

${ }^{47}$ Utility Dive, 2017 State of the Electric Utility Survey Report (2018), https://www.utilitydive.com/library/2017-state-of-the-electric-utility-survey-report/

${ }^{48}$ Christopher McGrory Klyza and David J. Sousa, American Environmental Policy: Beyond Gridlock, (Cambridge MA, MIT Press 2013); Robert MacNeil, 'Alternative climate policy pathways in the US', Climate Policy 13:2 (2013): 259-276.

${ }^{49}$ Elizabeth Bomberg, 'Environmental politics in the Trump era: an early assessment', Environmental Politics 26, no. 5 (2017): 956-963.
} 
In terms of progressive action on climate, the most important institutional counter to Trump's efforts will come through policy efforts at the state and local levels. Subnational efforts became a prominent feature of US climate policy under George W. Bush, as federal stagnation led environmentalists and other interest groups to redirect their efforts towards the country's state capitals. ${ }^{50}$ To that end, during the Bush years, a wide range of policies was adopted across numerous states to promote greater use of renewables, alternative fuel vehicles, and energy efficient appliances. While many activists turned their attention back towards Washington during the Obama years, this process of subnational action has once again become a primary focus, and is likely to proceed with greater clarity and momentum than before.

In direct response to Trump's withdrawal announcement, a large group of US governors declared the formation of the US Climate Alliance (USCA), mere hours after Trump's announcement. The USCA is a coalition of 17 states that have pledged to ignore Trump's withdrawal, and independently uphold the commitments made by the Obama administration under the PA. In so doing, these states have vowed to oversee in-state GHG emissions reductions of at least 26 percent below 2005 levels by 2025 - a target which many are on their way to achieving. ${ }^{51}$ The USCA (which collectively represents 47 percent of US GDP, 41 percent of the country's population, and nearly 40 percent of national emissions) will act as a forum for members to develop and strengthen their climate strategies through sharing of information and best practices, as well as collaborate on new mechanisms for financing clean energy projects, and improving building and construction standards, modernizing regional electricity grids. ${ }^{52}$

US cities, for their part, have also reaffirmed their commitment to the principles of the PA, with 398 mayors, representing close to 70 million Americans, signing on to the Mayors' National Climate Action Agenda. Added together, these states and cities have an economic might worth roughly $\$ 10$ trillion, making the group the second-largest economy in the PA (only China is larger). At COP23 in Bonn, these states and cities banded together with nearly 1000 US corporations (including 71 Fortune 100 companies) and almost 200 US universities and colleges to produce the 'We Are Still In' declaration, ${ }^{53}$ with each vowing to continue pursuing the US' Paris targets. There are currently proposals in place to have this coalition subject to the same monitoring and accountability mechanisms required from national governments under the PA. If accepted, these commitments could then be included as part of the US' national GHG inventory under the treaty.

There is good reason to believe that the renewed activity at the subnational level will indeed

\footnotetext{
${ }^{50}$ Barry Rabe, Greenhouse Governance: Addressing Climate Change in America (Washington: Brookings Institution, 2010). Under the US federal system, state governments may regulate any industrial activities within their borders, as long as it does not interfere with interstate commerce. In this context, they can impose any number of regulatory initiatives, including taxing carbon emissions, requiring utilities to use more renewable energy, strengthening building codes, creating tougher efficiency standards for appliances and automobiles, or implementing tougher agriculture policies, among many other options.

${ }^{51}$ Bloomberg New Energy Finance, 2018 Sustainable Energy in America Factbook, https://about.bnef.com/clean-energy-investment/). It is important to note that the US' Paris pledge of $26 \%$ below 2005 levels by 2025 is widely considered to be insufficient to avoid runaway climate change. According to Climate Action Tracker, if all countries took on pledges similar to the US, projected warming would greatly surpass the Paris agreement's safety threshold of $1.5^{\circ} \mathrm{C}$, and would likely reach closer to $3^{\circ} \mathrm{C}$. See Climate Action Tracker. 2019. Country Summary: United States, https://climateactiontracker.org/countries/usa/. ${ }^{52}$ Ten other states, which have chosen not to formally join the USCA, have reaffirmed their intention to keep emissions targets in line with the US' Paris pledge.

${ }^{53}$ We Are Still In, 'We Are Still In'Declaration (n.d.), https://www.wearestillin.com/we-are-still-declaration.
} 
be substantial, with most states already well on their way to establishing a suite of climate programs in light of Washington's inaction. A primary instrument tool has been the establishment of Renewable Portfolio Standards, which mandate that utilities generate a given percentage of their electricity from renewable sources (several states have also created socalled 'Clean Energy standards', which include nuclear and carbon capture technologies). By 2017, 30 states and two territories had implemented renewable and clean energy standards, with some of the more ambitious requirements coming from large states like New York and California (which have a combined population of approximately 60 million, and both have RPS targets of 50 percent by 2030).$^{54}$ Many states have also passed various laws mandating that new power plants meet strict carbon performance standards, while others have required utilities to invest in offsets for certain portions of their emissions. Thanks in large part to this increased deployment by states, in Trump's first year in office, renewable energy generation (including hydropower) reached 18 percent of total stationary power in the US. ${ }^{55}$ When combined with the coal-to-gas conversions noted above, these actions helped the US to simultaneously achieve its lowest per-capita GHG emissions in 25 years while still growing its economy. ${ }^{56}$

In so doing, states and cities are not only reducing their own domestic emissions, but also making it easier and cheaper for other governments (including Washington) to do likewise in the future through so-called 'policy learning'. As these early-movers invest time, money, and resources in developing thousands of different pilot programs and policies, they generate new knowledge and expertise that can lower barriers to climate policy development for other jurisdictions. ${ }^{57}$

There are, nevertheless, two important caveats that ought to dampen any optimism that subnational action is anywhere near sufficient at this point. First, USCA signatory states have achieved the vast majority of their emissions reductions simply by switching their electricity supplies from coal to natural gas. In addition to the shortcomings of this strategy noted above, it is also key to acknowledge that electricity is only responsible for 28 percent of US emissions (see Figure 2). The other 72 percent comes from transport, industrial processes, commercial and residential buildings, agriculture and waste. In all of these sectors, state action has been effectively non-existent. As a result, emissions from all of them have failed to adequately decline (see Figure 3), and the US will almost certainly fall well-short of its already-insufficient Paris targets - a recent analysis by the Rhodium Group suggests the US is on course for a mere 19 percent emissions reduction by 2025, as opposed to the 26 percent promised at Paris. ${ }^{58}$

\section{FIGURE 2 IN ABOUT HERE}

\footnotetext{
${ }^{54}$ Center for Climate and Energy Solutions, State Climate Policy (2018), https://www.c2es.org/content/stateclimate-policy/; Vicki Arroyo, 'The global climate action summit: increasing ambition during turbulent times', Climate Policy 18, no. 9 (2018): 1087-1093.

${ }^{55}$ Energy Information Administration, Annual Energy Outlook 2018, https://www.eia.gov/outlooks/aeo/

${ }^{56}$ EPA. US Greenhouse Gas Emissions Sources (Washington DC: US Environmental Protection Agency, 2018), https://www.epa.gov/ghgemissions/sources-greenhouse-gas-emissions

${ }^{57}$ Harriet Bulkeley, Cities and Subnational Governments, in The Oxford Handbook of Climate Change and Society, ed. David Schlosberg and Richard Norgaard (Oxford: Oxford University Press 2011), pp. 464-478; Robert MacNeil, 'Death and environmental taxes: why market environmentalism fails in liberal market economies', Global Environmental Politics, 16 (1), 21-37.

${ }^{58}$ Rhodium Group. Taking Stock 2017: Adjusting Expectations for US GHG Emissions (2017), http://rhg.com/reports/taking-stock-2017-adjusting-expectations-for-us-ghg-emissions.
} 
US Emissions by Sector, 2018

FIGURE 3 IN ABOUT HERE

US Emissions Trends, 1990-2016

Second, for the foreseeable future, it will remain politically, financially, and technically difficult for a small group of states to address the problem on their own. With so many laggard states content to collect the spoils of emissions and jobs 'leakage' from more proactive states, a race-to-the-bottom dynamic will continue to dampen the full potential of subnational action. This is why Obama's federal policies were an important start. While the initial targets were very weak, they nevertheless compelled the numerous states that lacked any decarbonization strategies to begin to imagine a cleaner future, and develop policies aimed at achieving it.

\section{Continuity \# 4: US subnational initiatives and transnational climate action}

Since the late 1990s, climate governance at the global level has been increasingly characterised as occurring through a highly diverse set of governance arenas and processes, rather than a single site of governance through the UNFCCC. Climate governance is thus often now characterised as a 'regime complex', a 'climate governance landscape', or a 'global climate governance complex', ${ }^{59}$ each of these terms denoting for the most part differing theoretical orientations rather than describing different empirical phenomena.

A good deal of the initiatives that make up this complex arise out of the initiatives of subnational actors - public and private - acting transnationally; that is, seeking to govern climate change, or aspects of it, across borders and often bypassing (or at least seeking to) central states. Some of this activity arises out of the perceived failures of the 'megamultilateral' process in the UNFCCC,${ }^{60}$ reflected in those initiatives in the US that arose in the early 2000s in reaction against Bush's climate policy, and now again against Trump's. This for example is the case for the most part with city networks like C40, and subnational emissions trading systems like RGGI and the Western Climate Initiative. Others, conversely, arose 'in the shadow' of the design of UNFCCC institutions, ${ }^{61}$ especially the 'flexibility mechanisms' in the Kyoto Protocol, which created a range of carbon markets in which NGOs and business groups then sought to intervene through a range of certification activities.

This transnational governance activity has become an increasingly significant part of the overall governance of climate change, to the extent that the UNFCCC itself seeks directly to

\footnotetext{
${ }^{59}$ See, respectively, Robert O. Keohane and David G. Victor, 'The Regime Complex for Climate Change', Perspectives on Politics 9, no. 1 (2011): 7-23; Michele Betsill, Navroz K. Dubash, Matthew Paterson, Harro van Asselt, Antto Vihma, and Harald Winkler, 'Building Productive Links between the UNFCCC and the Broader Global Climate Governance Landscape', Global Environmental Politics 15, no. 2 (2015): 1-10; Harriet Bulkeley, Liliana Andonova, Michele Betsill, Daniel Compagnon, Thomas Hale, Matthew Hoffmann, Peter Newell, Matthew Paterson, Charles Roger, and Stacy D VanDeveer, Transnational Climate Change Governance (Cambridge: Cambridge University Press, 2014).

${ }^{60}$ Matthew Hoffmann, Climate governance at the crossroads: experimenting with a global response after Kyoto (Oxford: Oxford University Press, 2011).

${ }^{61}$ Jessica F. Green, 'Order out of Chaos: Public and Private Rules for Managing Carbon', Global Environmental Politics 13, no, 2 (2013): 1-25.
} 
coordinate, or 'orchestrate', ${ }^{62}$ this activity. It has created some specific partnerships with organizations like $\mathrm{C} 40$, but also created the NAZCA portal to showcase subnational and nonstate initiatives in order to see their potential and create the possibility of coordination. ${ }^{63}$ Although not part of the formal document of the PA, these partnerships and coordination with non-state and subnational actors were very much part of the PA process and have continued in the UNFCCC since then. Orchestration is also carried out by national governments, and China's cooperation agreement with California can be seen as such an activity, reflecting again China's shift into global leadership on climate change. ${ }^{64}$

The US initiatives mentioned above are closely connected to these transnational initiatives. US cities play important roles in transnational city networks. Michael Bloomberg acted as chair of the C40 network in the latter stages of his mayorship in New York and transformed the organization from the initial one established by Ken Livingston when he was Mayor of London. US investors are key participants in investor initiatives like CDP and INCR. And US firms are heavily involved in transnational technology partnerships like REEEP and GMI. ${ }^{65}$ This transnational activity feeds back into action within the US in various ways.

But the transnational governance of climate change is changing in ways that have (at least) two important implications for the US' relationship to climate politics under Trump and beyond. On the one hand, many of these initiatives work to accentuate the tension between a fossil and a decarbonising bloc sketched above. The risk for the US, of course recognised by many actors within the US, is that the US (and other pro-fossil states such as in the Gulf, Australia, and perhaps Canada) get locked out of the political-economic benefits of decarbonising technologies. As the cycle of investments in renewable energy in particular continues to generate continued reduction in unit costs and thus self-feeding processes of shifts out of fossil fuels, those with particularly high sunk costs in fossil fuels fail to take adequate advantage of the new possibilities. The possibility of advanced battery storage enabling much higher market penetration of intermittent renewables is the next frontier of this transformation. Up to now, the US has remained at the forefront of this technology development. However this leadership is premised on relatively low levels (in most countries) of RE as a share of electricity: whether this leadership can survive while other countries get much further ahead in decarbonization and the US lags is unclear, even if it will lag less than many think, as suggested above.

The second novel dynamic in the transnational governance of climate change is in the resurgence of more combative social movement activity from the mid-2000s onwards. ${ }^{66}$ Central to this has been the renewed focus on fossil fuel extraction, and particularly with the explosion of protest activity around oil pipelines, fossil fuel divestment and anti-fracking protests from around 2012 onwards, and then more recently the explosion of direct action surrounding school strikes for climate (of whom the actions of Greta Thunberg have rapidly

\footnotetext{
${ }^{62}$ Thomas Hale and Charles Roger, 'Orchestration and transnational climate governance', Review of International Organizations 9, no. 1 (2014): 59-82.

${ }^{63}$ UNFCCC. 'Global Climate Action' (n.d.), http://climateaction.unfecc.int/.

${ }^{64}$ UNFCCC. 'California and China Sign Agreement on Climate and Cleantech' (n.d.), https://unfccc.int/news/california-and-china-sign-agreement-on-climate-and-cleantech.

${ }^{65}$ Bulkeley et al, Transnational Climate Change Governance.

${ }^{66}$ Jennifer Hadden, Networks in Contention, (Cambridge: Cambridge University Press, 2015); Harriet Bulkeley, Michele Betsill, Daniel Compagnon, Thomas Hale, Matthew Hoffmann, Peter Newell, and Matthew Paterson, 'Transnational Climate Change Governance: Charting New Directions Post-Paris', in Governing Climate Change: Polycentricity in Action?, ed. Andrew Jordan, Dave Huitema, Harro Van Asselt, and Johanna Forster (Cambridge: Cambridge University Press 2018), 63-80.
} 
become iconic) and Extinction Rebellion. The pipeline actions have a particular North American character, with protests over Keystone XL, DAPL, Northern Gateway, Energy East and Kinder Morgan pipelines, all designed to get Canadian tar sands oil more cheaply to market. FFD protests also started in the US but have rapidly become a widespread form of climate action, spreading from their original source in colleges and churches in the US to become a global movement strategy spreading to mainstream institutional investors, sovereign wealth funds (the Norwegian), large churches like the Church of England, and so on. Some of these developments may have contributed to the resurgence and reframing of climate action in the new Congress via the sunrise movement in the US and adoption of the notion of the 'Green New Deal'. ${ }^{67}$

The implications of these transnational governance activities on climate change is that even if the US under Trump does manage domestically to rollback various regulations that sought, however modestly, to 'bend the curve' on US GHG emissions, and to open up new areas for fossil fuel development, and doesn't participate in the activities of the UNFCCC except in an occasionally disruptive manner (as in its support for pro-coal activities at COP23 in $2017^{68}$ ), there are a number of ways in which the US economy and society either has opportunities to participate in transnational networks that limit the effect of federal government actions, and/or that transnational climate governance will have effects on US society, through investment activities, boycotts, or through the dynamics in the global market for low-carbon energy sources, that Trump will not be able to significantly affect.

\section{Conclusion}

It is not our intention here to argue that Trump is irrelevant, or that he does not represent a setback in all sorts of ways. Rather, it was our primary aim to show that, on the one hand, there are very significant continuities across different administrations in the US on climate policy which are effectively ignored when we focus on the narrative of 'Trump-as-disruptor'. Indeed, it is key to note that much of the perceived disjuncture under Trump stems from a tendency to overstate the achievements of the Obama administration. While Obama deserves credit for his leadership in orchestrating the PA and backing decarbonisation strategies at home, his overall achievements were decidedly modest. In addition to facilitating an explosion of oil and gas production (causing the US to become the biggest natural gas exporter in the world), Obama found himself hemmed in by a series of political, economic, and institutional constraints that prevented his administration from aiming higher on climate. As a result, his government submitted an INDC that ranked among the weakest of commitments for an industrialized economy (indeed, if all countries took on a similar commitment, the planet would massively surpass the 2 degrees Celsius safety threshold), and failed to even implement policies capable of achieving his insufficient goal. ${ }^{69}$

And on the other hand, we sought to show that, despite Trump's attempted rollback of various climate/energy regulations, there are a number of mechanisms and trends (domestic,

\footnotetext{
${ }^{67}$ David Roberts, 'There's now an official Green New Deal. Here's what's in it', Vox, February 7, 2019, https://www.vox.com/energy-and-environment/2019/2/7/18211709/green-new-deal-resolution-alexandriaocasio-cortez-markey.

${ }^{68}$ Damian Carrington, 'Tobacco at a Cancer Summit': Trump Coal Push Savaged at Climate Conference. The Guardian, November 13, 2017, http://www.theguardian.com/environment/2017/nov/13/bonn-climate-summittrump-fossil-fuels-protest.

${ }^{69}$ Arroyo, 'The global climate action summit'; Urpelainen and Van de Graaf, 'United States non-cooperation'.
} 
international and transnational) that mitigate significantly the tangible effect of his rollbacks on the global fight against climate change.

Nevertheless, given the limited time-scale, we need radical and immediate reductions, and in this context, Trump's interventions are extremely unhelpful. Within the US itself, the most worrying is in fact the shift to an association with a sort of 'climate fascism', where the racist, misogynist, authoritarian elements unleashed by Trump become associated with a pro-fossil fuel stance. ${ }^{70}$ But while worrying for other reasons, this is unlikely to affect emissions much, given the other trends we have detailed here. What, then, can pro-climate forces in the US plausibly do to ensure that Trump's four (or possibly eight) years can be used productively on climate? We close by offering three suggestions.

A first key priority ought to be building stronger Congressional support for federal R\&D investments in renewable and storage technologies. The US federal government is the most prolific developer of novel technologies in human history, and played a crucial role in launching countless technologies and sectors over the past century. ${ }^{71}$ This has been the case for renewables as well, with Washington funding the lion's share of the basic research that has underpinned the industry since the 1970s. ${ }^{72}$ These investments often take years to bear fruit (indeed, Washington's investments in fracking took more than twenty years to show results), but today's R\&D investments will be crucial for developing the technologies that will allow the world to sprint towards a net-zero carbon economy by mid-century. This will require ramping up $\mathrm{R} \& \mathrm{D}$ investments across a range of sectors, including for example, aviation, electric vehicles, industrial processes, alternative food proteins, agricultural processes, waste and recycling, and renewables and storage. Imagine, for example, a time in the mid 2030s when a household can purchase an ultra-efficient 10kw solar array with a $20 \mathrm{kWh}$ storage battery for under $\$ 1000$. Such a scenario would render fossil fuels completely uncompetitive in all but a few remaining industries. Federal R\&D programs are absolutely crucial for achieving this vision, and, indeed, may prove to be the most significant aspect of US climate policy. While Trump's 2018 budget proposal aimed to decimate these investments, Congressional support (particularly among Democrats, but also among many Republicans) allowed them to escape more or less unscathed. There may, therefore, be room to expand such programs moving forward. ${ }^{73}$

Second, pro-climate state governments need to invest significantly more in renewables (as opposed to natural gas), and focus on other sectors beyond just electricity. California's famed SB32 is a promising example for others to follow, with strategies aimed at systematically decarbonizing transportation, agriculture, industry, and buildings. ${ }^{74}$ Indeed, if subnational

\footnotetext{
${ }^{70}$ Cara Daggett, 'Petro-masculinity: Fossil Fuels and Authoritarian Desire', Millennium 47, no. 1 (2018): 25-44.

${ }^{71}$ Fred Block, 'Swimming Against the Current: The Rise of a Hidden Developmental State in the United States', Politics \& Society 36, no. 2 (2008): 169-206; Linda Weiss, America Inc.?: Innovation and Enterprise in the National Security State, (Ithaca NY: Cornell University Press, 2014); Mariana Mazzucato, The Entrepreneurial State: Debunking Public Vs. Private Sector Myths, (London, November 2015).

72 See Robert MacNeil, 'Seeding an energy technology revolution in the United States: Re-conceptualising the nature of innovation in 'Liberal-Market Economies', New Political Economy, 18:1 (2013), 64-88; Robert MacNeil, Neoliberalism and Climate Policy in the United States: From market fetishism to the developmental state, (London: Routledge, 2017).

${ }^{73}$ A further key aspect of continuity can be found in the US' continued involvement in a series of multilateral low-carbon R\&D forums and programs, including Mission Innovation, the APEC Energy Working Group, the Clean Energy Ministerial, the International Energy Agency, the International Renewable Energy Agency, the International Partnership for Energy Efficiency Cooperation, and the G20.

${ }^{74}$ See Brad Plumber, 'California is about to find out what a truly radical climate policy looks like', Vox Online, 29 August 2016, https://www.vox.com/2016/8/29/12650488/california-climate-law-sb-32.
} 
action is going to be the primary means of policy-induced emissions cuts in the US, activists and policymakers in these jurisdictions need to dramatically increase the scale and scope of their ambition.

And finally, pro-climate forces in the US simply need to keep their eyes peeled for interesting opportunities. The EPA's ability to unilaterally regulate carbon emissions (easily the greatest single advance in federal climate policy over the past generation) came about under the George W. Bush administration as the result of an unlikely lawsuit spearheaded by some forward-thinking activists. The Trump era could likewise contain the seeds of similar advances if activists and policymakers pay close attention to the numerous opportunities afforded by the peculiar structure of the American state, its legal system, and policy process. 


\section{Figure 1}

Trends in fuel mix in US electricity generation

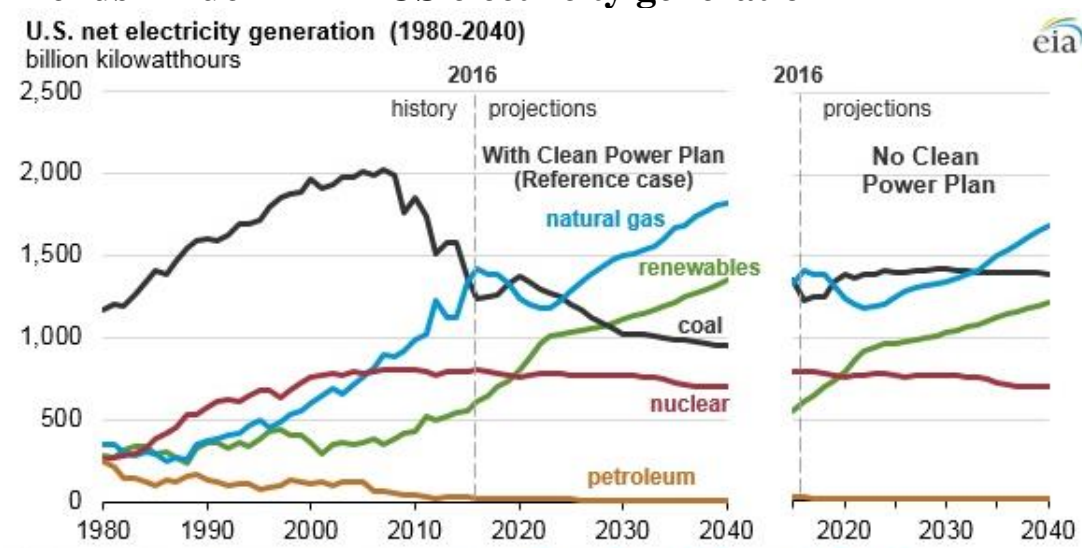

Energy Information Administration 2017

\section{Figure 2}

US Emissions by Sector, 2018

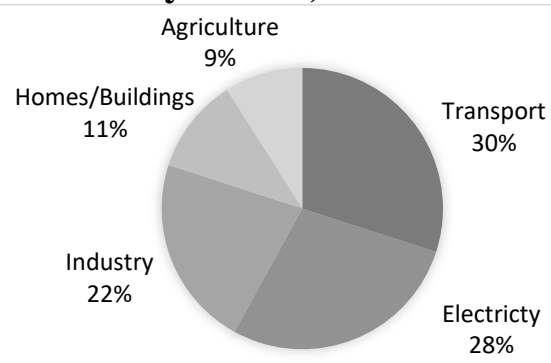

Source: EPA 2018

\section{Figure 3}

US Emissions Trends, 1990-2016

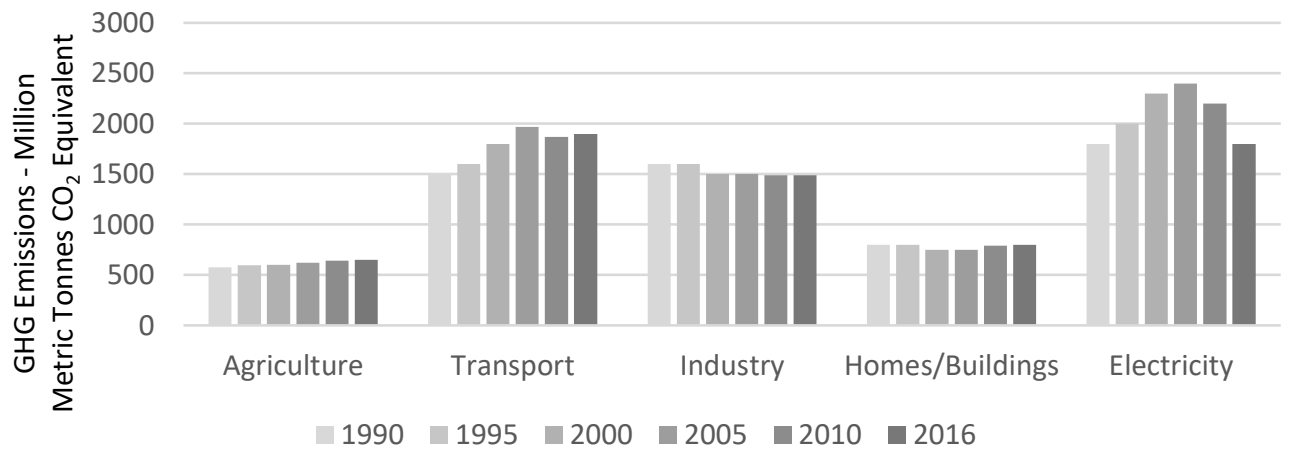

Source: EPA 2018 